\title{
AIR DRYING OF LOGS FROM AN Eucalyptus urophylla CLONE FOR CARBONIZATION USE
}

\author{
Raphael Nogueira Rezende ${ }^{1}$, José Tarcísio Lima², José Reinaldo Moreira da Silva², Alfredo Napoli, \\ Hélder Bolognani Andrade ${ }^{4}$, André Luiz Raimundo Faria ${ }^{5}$
}

(received: December 11, 2009; accepted: August 30, 2010)

\begin{abstract}
Wood drying is one of various stages in the carbonization process, therefore proper monitoring is key to improving yield and obtaining quality charcoal. Prior to being subjected to carbonization by charcoal production plants and once trees have been felled, $\operatorname{logs}$ are piled up by the roadside or close to carbonization furnaces and left air drying for 90 days until an optimal $30 \%$ moisture content is reached. This work aims to evaluate air drying of logs from an Eucalyptus urophylla clone for carbonization use, analyzing moisture reduction over time and also the influence of log diameter and bark. Logs with and without bark were used, $6.0 \mathrm{~cm}$ to $21.0 \mathrm{~cm}$ in diameter, $3.60 \mathrm{~m}$ in length, with average basic density of $0.496 \mathrm{~g} / \mathrm{cm}^{3}$, obtained from a commercial stand of Eucalyptus urophylla at age 8 years. Air drying log piles were arranged outdoors in Paraopeba, Minas Gerais State, Brazil and monitoring consisted of periodic $\log$ weighing for a period of 80 days. At the end of the experiment, higher rates of moisture loss were observed in the three initial weeks. Moisture in logs without bark (54\%) and with bark (50\%) was close after 80 drying days, with a higher level of moisture reduction being observed for logs without bark. Bark influence on moisture loss was more pronounced in the first three weeks. Moisture reduction varied in intensity as a function of log diameter. After 80 days, the highest level of moisture reduction was observed in logs without bark: $65 \%$ for logs larger in diameter and $80 \%$ for logs smaller in diameter. As regards logs with bark, results were $56 \%$ and $75 \%$ respectively.
\end{abstract}

Key words: Charcoal, log piles, moisture content.

\section{SECAGEM AO AR LIVRE DE TORAS DE UM CLONE DE Eucalyptus urophylla EMPREGADO NA CARBONIZAÇÃO}

\begin{abstract}
RESUMO: A secagem da madeira é uma das etapas do processo de carbonização e seu controle é de grande importância no rendimento e na qualidade do carvão vegetal produzido. Nas empresas produtoras de carvão, após o corte, a madeira é empilhada nas margens das estradas ou próxima aos fornos de carbonização e é carbonizada após 90 dias de secagem ao ar livre, quando se deseja alcançar 30\% de umidade. Neste trabalho, objetivou-se avaliar a secagem ao ar livre de toras de um clone de Eucalyptus urophylla empregado na produção de carvão vegetal, analisando-se a perda de umidade no tempo, influência da casca e do diâmetro das toras no processo. Foram utilizadas toras com casca e sem casca, com diâmetros variando de 6,0 a 21,0 cm, densidade básica média de 0,496 g/ $\mathrm{cm}^{3}$ e 3,60 m de comprimento, provenientes de um talhão comercial de Eucalyptus urophylla com 8 anos de idade. Pilhas de secagem ao ar livre foram instaladas em Paraopeba, Minas Gerais, Brasil e o acompanhamento da secagem foi realizado por pesagens periódicas das toras durante 80 dias. Ao final deste estudo, observou-se que as maiores perdas de umidade ocorreram nas três semanas iniciais. A umidade das toras sem casca (54\%) e com casca (50\%) foram próximas após 80 dias de secagem, com uma maior redução de umidade para as toras sem casca. A influência da casca na perda de umidade foi mais pronunciada nas três primeiras semanas. A redução de umidade ocorreu em intensidades diferentes em função do diâmetro das toras. Após 80 dias, a maior redução de umidade foi observada nas toras sem casca: 65\% para as toras de maiores diâmetros e $80 \%$ para as de menores diâmetros. Já, para as toras com casca os resultados foram respectivamente $56 \%$ e $75 \%$.
\end{abstract}

Palavras-chave: Carvão vegetal, pilhas de toras, teor de umidade.

\section{INTRODUCTION}

Brazil is one of the world's largest producers and consumers of charcoal. In 2005 alone, the country produced
9.5 million tons of charcoal $-25 \%$ of the worldwide total (Associação Mineira de Silvicultura-AMS 2008). On a nationwide scale, Minas Gerais stands out as the largest producer and consumer, producing about $80 \%$ and

${ }^{1}$ Forest Engineer, PhD candidate in Wood Science and Technology - Departamento de Ciências Florestais - Universidade Federal de Lavras/UFLA - Cx. P. 3037 - 37200-000 - Lavras, MG - raphaelfloresta@ hotmail.com

${ }^{2}$ Forest Engineer, Professor Dr. in Forest Engineering - Departamento de Ciências Florestais - Universidade Federal de Lavras/UFLA - Cx. P. 3037 - 37200-000 - Lavras, MG - jtlima@dcf.ufla.br, jreinaldo@dcf.ufla.br

${ }^{3}$ Materials scientist, Researcher at CIRAD/França - Departamento de Ciências Florestais - Universidade Federal de Lavras/UFLA - Cx. P. 3037 - 37200-000 - Lavras, MG - alfredo.napoli@cirad.fr

${ }^{4}$ Forest Engineer - V\&M Florestal LTDA - CAPEF - Fazenda Itapoã - Cx. P. 04 - Paraopeba, MG - helder@vmtubes.com.br ${ }^{5}$ Bachelor's degree candidate in Forest Engineering - Departamento de Ciências Florestais - Universidade Federal de Lavras/UFLA - Cx. P. 3037 - 37200-000 - Lavras, MG - andreluiz.ufla@ gmail.com 
consuming $66 \%$ of the total domestic charcoal production (PEREIRA \& SANTOS 2008).

Several sectors of the economy employ charcoal as source of raw material, with pig iron, iron alloy and cement industries consuming $90 \%$ of the total charcoal produced (AMS 2008). The steel industry is responsible for a large proportion of this consumption, thus making the input material a key element in adding value to the final product (steel). In terms of competitiveness in the Brazilian steel industry, there are some advantages in using charcoal in relation to mineral coal: a renewable resource, less polluting, with low concentration of ashes, phosphorus and sulfur, carbon fixation ( $75 \%$ to $85 \%$ ), decentralized transportation, foreign capital savings with elimination of fossil fuel imports, creation of field jobs etc. (ASSIS 2010, MORELLO 2009).

Properties of charcoal are closely related to the source raw material. Variability in intrinsic properties of the of wood, including lignin content, basic density, size of originating pieces and moisture, all exert great influence on charcoal quality (MENDES et al. 1982).

Any recently felled woody plant has considerable amounts of water, which should be partially removed through drying prior to charcoal production.

According to Hart (1966), drying is defined as being dynamic equilibrium between heat transfer from air to wood, evaporation surface, moisture diffusion through the piece and movements of free water. Air drying consists of exposing wood to the action of local climate factors, the method being widely used in Brazil on account of its favorable environmental conditions (KLITZKE 2003).

According to Raad (2004), drying is one of the various stages in the carbonization process, therefore process monitoring throughout is of crucial importance. Moisture content influences control of the carbonization process, as it can affect the wood's calorific power, carbonization time, furnace temperature, heating speed and productivity, charcoal friability and gravimetric yield (JUVILLAR 1979, OSSE 1971). Water presence in wood implies reduced calorific power, due to greater demand for energy input in order to heat and evaporate the existing moisture and, additionally, in carbonization furnaces that energy input is generated by the burning of part of the wood being carbonized (CARNEIRO 2007, VIANA et al. 2006). While studying different species for energy generation, Cunha et al. (1989) noted that the higher the moisture content in wood, the lower its combustion power, a result of the water evaporation process absorbing energy throughout the burning. Charcoal production using moist wood generates friable, crumbly charcoal and increases the fine powder content, during manipulation and transportation (VALENTE \& LELES 1986). Wood with higher moisture contents affects carbonization productivity. After investigating carbonization of Eucalyptus logs in a gas recycling furnace as carried out by V\&M Florestal, Fávero et al. (2007) noted that gravimetric yield increased from $28 \%$ to $40 \%$ as moisture content dropped from $30 \%$ to $18 \%$.

Mendes et al. (1982) argue that, in order to obtain good furnace productivity, moisture content should be about 30\%. Valente \& Lelles (1986) suggest that wood should enter a carbonization furnace with a dry-basis moisture content of $20 \%$ to $30 \%$. Farinhaque (1981) argues that moisture content should be below $25 \%$ for the reason that contents above this level strongly reduce the amount of energy, the temperature of the burning chamber and the temperature of exhaust gases, in addition to soot crusts forming inside the combustion chamber. While studies about moisture content control and air drying of logs for charcoal production are critical, they are few and scarce in Brazil. Charcoal production companies usually have trees limbed, sawn into logs and barked in the field, then piled up and left to dry outdoors for 90 days, either in the cultivation plot or in areas close to carbonization furnaces (JUVILLAR 1979, VITAL et al. 1985).

Given the above context, the aim of this work is to evaluate air drying of logs from an Eucalyptus urophylla clone for use in charcoal production, analyzing moisture content reduction throughout and the influence of bark and diameter on the process.

\section{MATERIAL AND METHODS}

The wood used in this study was obtained from a stand owned by V\&M Florestal LTDA, located in Itapoã farm, in Paraopeba region, Minas Gerais State, Brazil at an altitude of $730 \mathrm{~m}$ to $750 \mathrm{~m}$. The local climate was characterized as subtropical humid, with average annual temperatures, relative humidity and precipitation of $20.9^{\circ} \mathrm{C}$, $70.5 \%$ and $1,236 \mathrm{~mm}$ respectively (BRASIL 1992, RIBEIRO \& WALTER 1998).

Twenty trees were felled from an Eucalyptus urophylla clone cultivated for charcoal production, at age 8 years, with trees separated by spacings of $3.0 \times 3.0 \mathrm{~m}$. Ten trees were barked and ten were left with bark. Average bark thickness was obtained using a digital caliper accurate to $0.01 \mathrm{~mm}$. 
Each tree was cut into $6 \operatorname{logs}$, each $3.60 \mathrm{~m}$ in length. From each log end a disc $3.0 \mathrm{~cm}$ in thickness was removed and divided into four quarters, two opposing quarters were used for determination of moisture content and the other two were used for determination of basic density. The procedure followed ABNT Standard NBR11941/2003 (Associação Brasileira de Normas Técnicas-ABNT 2003). The value adopted as initial moisture content was the average moisture content of two discs from the same log, according to the methodology adopted by Calonego et al. (2006) and Rasmussen (1961).

Logs were individually weighed using an electronic scale with a capacity of $300 \mathrm{~kg}$, accurate to $0.2 \mathrm{~kg}$. The dry matter was estimated directly on the basis of initial log mass and moisture content values (gravimetric method).

Two log piles with bark and two log piles without bark were arranged outdoors in Paraopeba, Minas Gerais State, Brazil Each pile consisted of six logs lying side by side and five logs stacked one on top of the other, arranged $1.20 \mathrm{~m}$ away from the adjacent pile and laid over two beams, perpendicular to wind direction.

Each pile contained moisture controller logs (MCL) arranged in the central portion of the pile (Figure 1) that were weighed for a period of 80 days. Air drying started in June/2009. Up until week 6 weighing was done weekly and from week 6 onward, fortnightly.

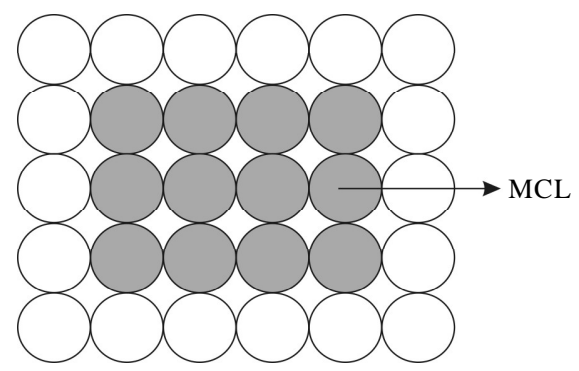

Figure 1 - Outline of an air drying $\log$ pile with moisture controller logs (MCL).

Figura 1 - Esquema de uma pilha de secagem ao ar livre e toras controladoras de umidade (MCL).

Log moisture content over time was determined by Equation 1.

$$
\mathrm{MC} \%=\frac{\mathrm{gm}-\mathrm{dm}}{\mathrm{dm}} \times 100
$$

where:

$\mathrm{MC} \%=\log$ moisture content $(\%)$;

$\mathrm{gm}=$ green mass $(\mathrm{kg})$;

$\mathrm{dm}=$ dry mass $(\mathrm{kg})$.
Average moisture content in logs with bark and without bark was derived from the arithmetic mean of moisture controller logs (MCL).

Cubic scaling of logs was conducted according to Smalian's method (BARROS et al. 2008).

Statistical analysis of moisture variation in logs with bark and without bark as a function of drying days was fitted to a regression analysis with a nominal significance level of $5 \%(\alpha=0.05)$. A mathematical model suggested by Vital et al. (1985) was used, relating variations in moisture content (MC) with number of drying days. The measures of accuracy used for fitted model were the coefficient of determination $\left(\mathrm{R}^{2}\right)$ and residual standard error (Syx).

A model identity test was done to verify the existence of a common equation to represent the data set of logs with and without bark.

A correlation analysis was performed to verify the relationship between reduction in moisture content and different diameters of logs with and without bark.

\section{RESULTS AND DISCUSSION}

Average results of log volume with and without bark, initial moisture content, basic density and diameter range are presented in Table 1. Average log bark thickness was $11.13 \mathrm{~mm}$.

Table 1 - Means of log volume, initial moisture content, basic density and diameter of $\log$ with and without bark for a $E$. urophylla clone.

Tabela 1 - Valores médios de volume, umidade inicial, densidade básica e diâmetro de toras com casca e sem casca de um clone de E. urophylla.

\begin{tabular}{lcc}
\hline Variable & Without bark & With bark \\
\hline Volume $\left(\mathrm{m}^{3}\right)$ & 0.0483 & 0.0496 \\
Initial moisture content $(\%)$ & 137 & 125 \\
Basic density $\left(\mathrm{g} / \mathrm{cm}^{3}\right)$ & 0.488 & 0.504 \\
Diameter range $(\mathrm{cm})$ & $6.0-20.0$ & $6.0-21.0$ \\
\hline
\end{tabular}

Basic density results are in agreement with results found in literature for species Eucalyptus urophylla. Ferreira (1994) found values between 0.480 and $0.500 \mathrm{~g} /$ $\mathrm{cm}^{3}$ and Evangelista (2007) found values between 0.450 and $0.500 \mathrm{~g} / \mathrm{cm}^{3}$.

Figure 2 illustrates air drying curves of logs without bark and logs with bark from a E. urophylla clone, during 80 days, in Paraopeba, Minas Gerais State, Brazil.

Greater levels of moisture loss were observed in drying week 1 , which is in agreement with findings of Ferreira

Cerne, Lavras, v. 16, n. 4, p. 565-572, out./dez. 2010 


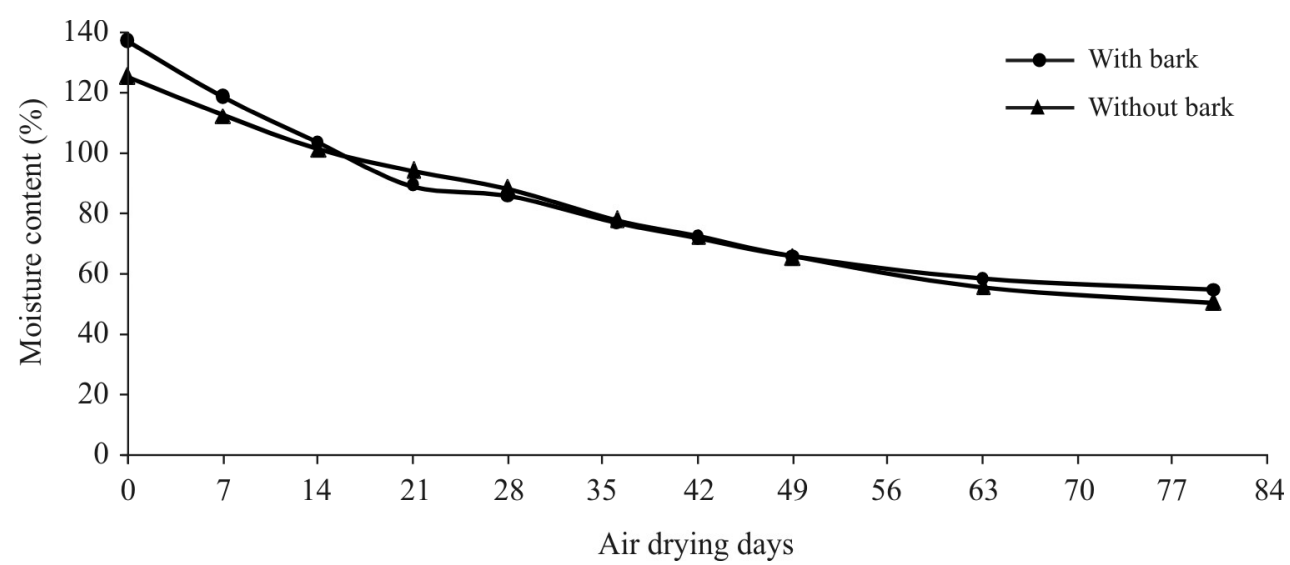

Figure 2 - Air drying curves of logs with bark and without bark from an Eucalyptus urophylla clone, during 80 days, in Paraopeba, Minas Gerais State, Brazil.

Figura 2 - Curvas de secagem ao ar livre de toras com casca e sem casca de clone de Eucalyptus urophylla em Paraopeba, Minas Gerais, Brasil durante 80 dias.

et al. (1983). In weeks 2 and 3, moisture loss levels for logs with bark and without bark were lower (Table 2). From week 4, logs with bark and without bark had their moisture contents reduced in similar proportions, as observed by Vital et al. (1985), who noted also that bark presence exerts greater influence on moisture loss in the first four weeks. After 80 drying days, moisture content results were close for logs without bark (54\%) and with bark (50\%), yet above the $30 \%$ desired for carbonization (MENDES et al. 1982), which means they require longer drying time in the field in order to reach the desired level. An analsysis of total moisture reduction over the 80-day drying time revealed greater reduction in logs without bark than in logs with bark (Table 2).

In this study, logs reached lower moisture levels and showed greater reduction in moisture contents than results obtained by Souza (2009). This author analyzed air drying of logs without bark $2.20 \mathrm{~m}$ in length from a commercial Eucalyptus clone in two cities of Vale do Rio Doce region, Minas Gerais State, Brazil ,looking to reduce transportation costs from field to plant yard. He noted, after 80 days, that average log moisture content (basic density of $0.488 \mathrm{~g} / \mathrm{cm}^{3}$ ) under severe climate conditions was $60 \%$, a total moisture reduction of $53 \%$, while in the city with milder climate conditions the average moisture content was $67 \%$, with a total reduction of $46 \%$. Vital et al. (1985), while studying air drying of E. grandis logs $1.30 \mathrm{~m}$ in length in Viçosa/MG, observed that logs without bark reached 53\% moisture content after 80 days while logs with bark reached $82 \%$, corresponding to a total moisture reduction of $76 \%$ and $57 \%$ respectively.

Cerne, Lavras, v. 16, n. 4, p. 565-572, out./dez. 2010
The regression analysis generated an equation (2) to explain moisture variation as a function of number of days for $\log$ s with bark and without bark from a $E$. urophylla stand in Paraopeba, Minas Gerais State, Brazil. The model identity test revealed that a general equation can be used for logs with bark and without bark.

$\ln ($ moisture content $)=5.05465-0.00714794 \mathrm{x}$ days $0.127257 \mathrm{x} \ln$ (days)

The coefficient of determination $\left(\mathrm{R}^{2}\right)$ indicated that $98.3 \%$ of moisture variations relative to drying time were explained by Equation 2. The residual standard error indicated that, on average, actual moisture values are varying by $2.3 \%$ in relation to estimated values. Satisfactory moisture estimations can be obtained using Equation 2.

Figure 3 provides drying curves of logs from two trees with bark and from two trees without bark with varying diameters, after 80 drying days, from the $E$. urophylla clone in Paraopeba, Minas Gerais State, Brazil.

Figure 3 reveals that after 80 drying days the average moisture content of logs without bark was $63 \%$ and $42 \%$ for larger and smaller diameter classes respectively. For logs with bark, results were $63 \%$ and $43 \%$ respectively. Although moisture values are similar after 80 days, it can be said that moisture losses occurred at different intensities in logs with bark and without bark with differing diameters (Table 3). Galvão \& Jankowsky (1985) and Ponce \& Watai (1985) argue that wood drying is strongly influenced by thickness or distance for movement of water. After studying air drying of $E$. grandis logs, Vital et al. (1985) affirmed that 
Table 2 - Moisture reduction (\%) in relation to drying time in logs with bark and without bark from a E. urophylla clone in Paraopeba, Minas Gerais State, Brazil.

Tabela 2 - Redução de umidade (\%) em relação ao tempo de secagem para toras com casca e sem casca de um clone de E. urophylla em Paraopeba, Minas Gerais, Brasil.

\begin{tabular}{lccccc}
\hline \multirow{2}{*}{ Logs } & \multicolumn{3}{c}{ Drying time (days) } & \multicolumn{2}{c}{ /day } \\
\cline { 2 - 5 } & 7 & 14 & 21 & Total after 80 days \\
\hline Without bark & $19 \%$ & $15 \%$ & $14 \%$ & $83 \%$ & 1.03 \\
With bark & $13 \%$ & $11 \%$ & $7 \%$ & $75 \%$ & 0.94 \\
\hline
\end{tabular}

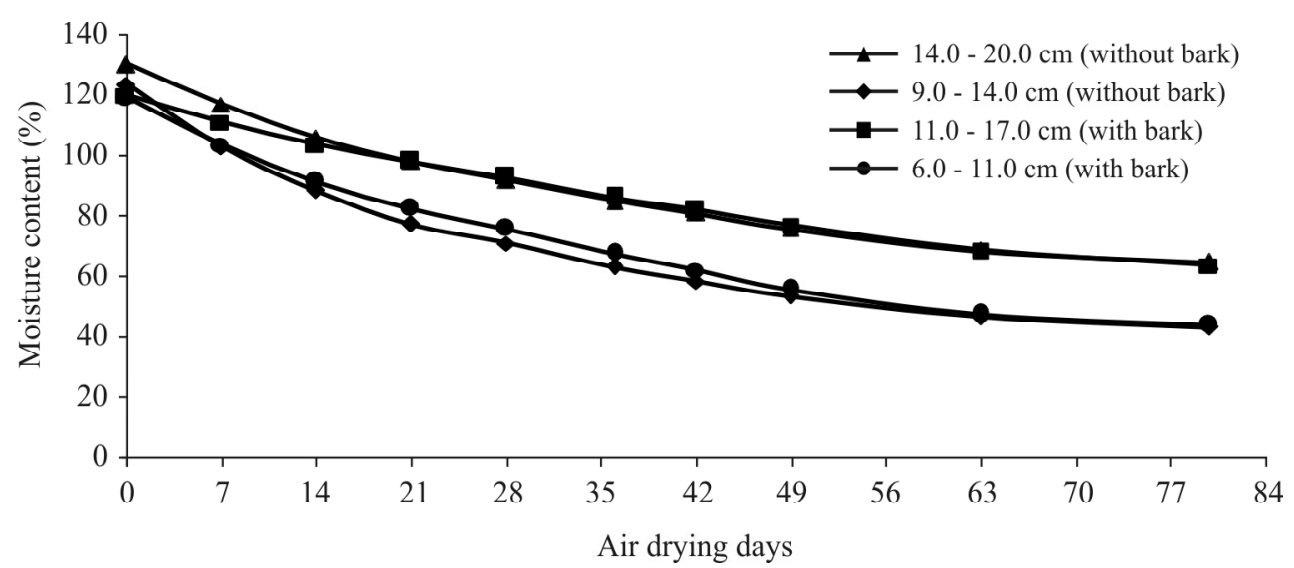

Figure 3 - Air drying curve of logs with bark and without bark with differing diameters from an E. urophylla clone in Paraopeba, Minas Gerais State, Brazil, after 80 drying days.

Figura 3 - Curva de secagem ao ar livre de toras com casca e sem casca de diferentes diâmetros de um clone de E. urophylla em Paraopeba, Minas Gerais, Brasil, durante 80 dias.

Table 3 - Reduction in moisture content (\%) in relation to drying time for logs with bark and without bark with different diameters from a E. urophylla clone in Paraopeba, Minas Gerais State, Brazil, and coefficient of correlation between moisture loss and log diameters.

Tabela 3 - Redução de umidade (\%) em relação ao tempo de secagem para toras com casca e sem casca de diferentes diâmetros de um clone de E. urophylla em Paraopeba, Minas Gerais, Brasil e coeficiente de correlação entre a perda de umidade e os diâmetros das toras.

\begin{tabular}{|c|c|c|c|c|c|c|c|}
\hline \multirow{2}{*}{ Logs } & \multirow{2}{*}{$\begin{array}{l}\text { Diameter class } \\
\qquad(\mathrm{cm})\end{array}$} & \multicolumn{5}{|c|}{ Drying time (days) } & \multirow{2}{*}{ Correlation (r) } \\
\hline & & 7 & 14 & 21 & 28 & Total in 80 days & \\
\hline \multirow{2}{*}{ W/o bark } & $14.0-20.0 \mathrm{~cm}$ & $13 \%$ & $11 \%$ & $8 \%$ & $6 \%$ & $65 \%$ & \multirow{2}{*}{-0.9523} \\
\hline & $9.0-14.0 \mathrm{~cm}$ & $21 \%$ & $15 \%$ & $11 \%$ & $6 \%$ & $80 \%$ & \\
\hline \multirow{2}{*}{ With bark } & $11.0-17.0 \mathrm{~cm}$ & $9 \%$ & $7 \%$ & $6 \%$ & $5 \%$ & $56 \%$ & \multirow{2}{*}{-0.9479} \\
\hline & $6.0-11.0 \mathrm{~cm}$ & $15 \%$ & $12 \%$ & $9 \%$ & $6 \%$ & $75 \%$ & \\
\hline
\end{tabular}

moisture reduction is affected by $\log$ diameter. These authors noted, after 84 days of air drying in Viçosa/MG, that the average moisture content in logs over $12.0 \mathrm{~cm}$ in diameter was $90 \%$, while in logs 8.0 to $12.0 \mathrm{~cm}$ in diameter moisture was $70 \%$, and in logs 4.0 to $8.0 \mathrm{~cm}$ in diameter average moisture was $56 \%$.

Cerne, Lavras, v. 16, n. 4, p. 565-572, out./dez. 2010 
At the end of the drying period it was noted that, even if with larger diameters which affects the rate of water release, results of total moisture reduction were higher for logs without bark $-65 \%$ in logs within the large diameter class and $80 \%$ in logs within the small diameter class-, while results for logs with bark were $56 \%$ and $75 \%$ respectively.

Correlations were found to be high, revealing a close relationship between moisture reduction and log diameter. As was expected, a significant negative correlation was found, indicating that as diameter increases moisture loss decreases.

Equations and measures of accuracy to explain moisture variation as a function of drying days for logs with bark and without bark with differing diameters are illustrated in Table 4. It was drawn from the model identity test that a general equation can be used for logs with bark and without bark within larger diameter classes and another common equation can be used to explain moisture variations in logs with bark and without bark within smaller diameter classes.

Upon analysis of measures of accuracy (Table 4), model fittings were found satisfactory. Good moisture estimations as a function of drying time can be obtained for $\log$ s with bark and without bark with differing diameters by using the model adopted by Vital et al. (1985).

Table 4 - Equations, coefficient of determination $\left(\mathrm{R}^{2}\right)$ and residual standard error (Syx) of moisture variation in logs with bark and without bark with different diameters as a function of drying time in Paraopeba, Minas Gerais State, Brazil.

Tabela 4 - Equações, coeficiente de determinação $\left(R^{2}\right)$ e erro padrão residual (Syx) obtidos para a variação de umidade das toras com casca e sem casca de diferentes diâmetros de um clone de E. urophylla em função do tempo de secagem em Paraopeba, Minas Gerais, Brasil.

\begin{tabular}{|c|c|c|c|}
\hline Diameter classes $(\mathrm{cm})$ & Model fitting & $\mathrm{R}^{2}(\%)$ & Syx $(\%)$ \\
\hline $\begin{array}{l}14.0-20.0 \\
\text { (w/o bark) } \\
11.0-17.0 \\
\text { (with bark) }\end{array}$ & $\ln \mathrm{MC}=4.93111-0.00568704 \mathrm{x}$ days $-0.082202 \mathrm{x} \ln$ (days) & 84.3 & 5.3 \\
\hline $\begin{array}{c}9.0-14.0 \\
\text { (w/o bark) } \\
6.0-11.0 \\
\text { (with bark) }\end{array}$ & $\ln \mathrm{MC}=5.02706-0.00720964 \mathrm{x}$ days $-0.172327 \mathrm{x} \ln$ (days) & 82.6 & 6.1 \\
\hline
\end{tabular}

\section{CONCLUSIONS}

Greater losses of moisture content occurred in the first three weeks, decreasing afterward.

The influence of bark on moisture reduction was more pronounced in the three initial drying weeks.

Moisture content in logs without bark (54\%) and with bark (50\%) was close after 80 drying days, with greater reduction in moisture content being noted in logs without bark.

Moisture content reduction occurred at different intensities as a function of $\log$ diameter, with greater moisture losses being noted in logs without bark and smaller diameters.

\section{ACKNOWLEDGMENTS}

We wish to thank Fundação de Amparo à Pesquisa do Estado de Minas Gerais (FAPEMIG - Process CAG APQ-4881-3.10/07) and V\&M Florestal LTDA.

\section{BIBLIOGRAPHICAL REFERENCES}

ASSIS, C. O. de. Vantagens do carvão vegetal [mensagem pessoal].Mensagem recebida por 〈raphaelfloresta@ hotmail.com> em 28 abr. 2010.

ASSOCIAÇÃO BRASILEIRA DE NORMAS TÉCNICAS. NBR 11941: madeira: determinação da densidade básica. Rio de Janeiro, 2003. 6 p.

ASSOCIAÇÃO MINEIRA DE SILVICULTURA. Anuário estatístico 2007. Disponível em: com.br/>. Acesso em: 16 set. 2008.

BARROS, M. V.; FINGER, C. A. G.; SCHNEIDER, P. R.; SANTINI, E. J. Fator de cubicação para toretes de Eucalyptus grandis e sua variação com o tempo de exposição ao ambiente. Ciência Florestal, Santa Maria, v. 18, n. 1, p. 109-119, jan./mar. 2008.

Cerne, Lavras, v. 16, n. 4, p. 565-572, out./dez. 2010 
BRASIL. Ministério da Agricultura e Reforma Agrária. Departamento Nacional de Meteorologia. Normais climatológicas: série 1961/1990. Brasília, 1992. 84 p.

CALONEGO, F. W.; BATISTA, W. R.; SEVERO, E. T. D.; SANTOS, J. E. G.; RIBAS, C. Avaliação do teor de umidade da madeira de Eucalyptus grandis por medidores elétricos resistivos. Instituto Florestal, São Paulo, v. 18, p. 71-78, dez. 2006.

CARNEIRO, A. de C. Qualidade da madeira e tecnologias para produção de carvão vegetal. In: SEMINÁRIO FLORESTAS PLANTADAS DO MS, 1., 2007, Campo Grande. Anais... Campo Grande, 2007. Disponível em: < http:// IWww reflore.org.br/palestras/QualidadeDaMadeira

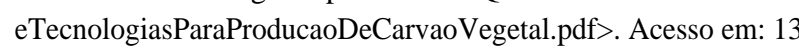
ago. 2008

CUNHA, P. S. C.; PONTES, C. L. F.; CRUZ, I. de A.; CABRAL, M. T. de F. D.; NETO Z. B. da C.; BARBOSA, A. P. R. Estudo químico de 55 espécies lenhosas para geração de energia em caldeiras. In: ENCONTRO BRASILEIRO EM MADEIRAS E EM ESTRUTURAS DE MADEIRA, 3., 1989, São Carlos. Anais... São Carlos, 1989. v. 2, p. 95-121.

EVANGELISTA, W. V. Caracterização da madeira de clones de Eucalyptus camaldulensis Dehnh e Eucalyptus urophylla S.T. Blake, oriunda de consórcio agrossilvopastoril. 2007. 120 p. Dissertação (Mestrado em Ciência Florestal) Universidade Federal de Viçosa, Viçosa, 2007.

FARINHAQUE, R. Influência da umidade no poder calorífico da madeira de Bracatinga (Mimosa scrabella, Benth) e aspectos gerais de combustão. Curitiba: FUPEF, 1981. 14 p. (Série técnica).

FÁVERO, G. C.; VALLE, R. M.; DUARTE, T. M. Análise térmica de um sistema de combustão de alcatrão em fornos retangulares para secagem da madeira. In:CONGRESSO IBEROAMERICANO DE ENGENHARIA MECÂNICA, 8., 2007, Cusco. Anais... Cusco: Federación Iberoamericano de Ingeniería Mecánica, 2007. p. 639-646. Disponível em:< http:// iwww.pucp.edu.pelcongreso/cibims/pdf/06/06-09.pdfs. Acesso em: 17 set. 2009.

FERREIRA, M. Características da madeira de espécies / procedências / árvores superiores e clones de Eucalyptus: revisão aplicada ao melhoramento para produção de pasta celulósica. In: REUNIÃO REGIONAL SOBRE CLONAGEM INTENSIVA
EM EUCALYPTUS, 1., 1994, Aracruz. Anais... Aracruz: IPEF, 1994. p. 1-18.

FERREIRA, M. C.; FERNANDES, P. S.; SARAIVA FILHO, J. C. Variação na umidade da madeira de eucalipto estocada em pátio industriais. In: CONGRESSO FLORESTAL BRASILEIRO, 4., 1982, Belo Horizonte. Anais... Belo Horizonte: SBS/IBDF/CNPq/FINEP, 1983. P. 779-781.

GALVÃO, A. P. M.; JANKOWSKY, I. P. Secagem racional da madeira. São Paulo: Nobel, 1985. 111 p.

HART, C. A. The drying of wood. Raleigh: North Carolina Agricultural Extension Service, 1966. 24 p.

JUVILLAR, J. B. O carvoejamento da madeira e seus reflexos na qualidade do carvão: qualidade da madeira. Piracicaba: IPEF, 1979. 6 p. (IPEF. Circular técnica, 64). Disponível em: <http:// iwww.ipế.br/publicacoes/ctecnica//nr064.pdf $>$. Acesso em: 13 jan. 2009.

KLITZKE, R. J. Secagem da madeira. Curitiba: UFPR, 2003. $98 \mathrm{p}$.

MENDES, M. G.; GOMES, P. A.; OLIVEIRA, J. B. Propriedades e controle da qualidade do carvão vegetal. In: FUNDAÇÃO CENTRO TECNOLÓGICO DE MINAS GERAIS. Produção e utilização de carvão vegetal. Belo Horizonte: CETEC, 1982. p. 77-89.

MORELLO, T. F. Carvão vegetal e siderurgia: de elo perdido a solução para um mundo pós-kyoto. 2009. 171 p. Dissertação (Mestrado em Economia) - Universidade de São Paulo, São Paulo, 2009.

OSSE, L. Lenha, carvão e carvoejamento. Brasil Florestal, Rio de Janeiro, v. 2, p. 32-80, 1971.

PEREIRA, J. M. M.; SANTOS, G. P. Aspectos socioeconômicos do setor florestal brasileiro. Informe Agropecuário, Belo Horizonte, v. 29, n. 242, p. 7-13, jan./fev. 2008.

PONCE, R. H.; WATAI, L. T. Manual de secagem da madeira. Brasília: STI/IPT, 1985. 72 p.

RAAD, T. J. Simulação do processo de secagem e carbonização do Eucalyptus spp. 2004. 114 p. Tese (Doutorado em Engenharia Mecânica) - Universidade Federal de Minas Gerais, Belo Horizonte, 2004.

Cerne, Lavras, v. 16, n. 4, p. 565-572, out./dez. 2010 
RASMUSSEN, E. F. Dry kiln operator's manual. Madison: USDA, 1961. $188 \mathrm{p}$.

RIBEIRO, J. F.; WALTER, B. M. T. Fitofisionomias do bioma Cerrado. In: SANO, S. M.; ALMEIDA, S. P. Cerrado, ambiente e flora. Planaltina: Embrapa - Cerrados, 1998. p. 89-166.

SOUZA, E. Efeito do tempo de secagem nas características físicas e químicas da madeira para produção de celulose [mensagem pessoal]. Mensagem recebida por <raphaelfloresta@hotmail.com> em 9 nov. 2009.
VALENTE, A. F.; LELLES, J. G. Carbonização da Madeira de Eucalyptus. Informe Agropecuário, Belo Horizonte, v. 12, n. 141, p. 74-79, set. 1986.

VIANA, E.; REZENDE, M. E. A.; PINHEIRO, P. C. da C.; SAMPAIO, R. S. A produção de carvão vegetal: teoria e prática. Belo Horizonte: [s.n.], 2006. 93 p.

VITAL, B. R.; DELlA LUCIA, R. M.; VALENTE, O. F. Estimativa do teor de umidade de lenha para carvão em função do tempo de secagem. Árvore, Viçosa, v. 9, n. 1, p. 10-27, ago. 1985. 